\title{
CORPORATE ENVIRONMENTAL ACCOUNTING AND REPORTING: DISCLOSURE AND DETERMINANTS OF PHARMACEUTICAL COMPANIES
}

\section{KAVITA}

Department Of Management, I.K.G. Punjab Technical University, Jalandhar, Punjab, India

The Corporate Social Responsibility accommodates businesses in building the Social, Economic and Environmental imperatives and if the firm's wants to grab the full opportunities then transparency is the important aspect for every organization. This study investigated the CSR disclosure association with performance attributes of Indian pharma companies. The study examined the relation of corporate environmental and corporate social responsibility disclosure with age, asset and turnover hypotheses were created to synchronizethe objectives of the study. The study used the secondary data as to examine corporate environmental and socialdisclosure; it required the annual reports of the companies and afterwards disclosure measured through the self constructed index. The study used the liner regression methodto analyze the disclosure. In the conclusion part study revealed that the corporate environment disclosure had the significant relation with Age, Turnover, and Assets of the companies it has been suggested that the companies need to adopt uniform accounting and reporting standards to increase the effectiveness and control for environment. It has been found in the results that the companies less in age have blow level of disclosure then the old companies, similarly companies have huge amount of assets and turnover.

KEYWORDS: Corporate Social Responsibility, Corporate Environmental Accounting, Corporate Disclosure, Index Constructed, Corporate Performance Index
\end{abstract}

Received: Jun 08, 2020; Accepted: Jun 28, 2020; Published: Aug 31, 2020; Paper Id.: IJMPERDJUN2020988

\section{INTRODUCTION}

These days, the stakeholders, shareholders, all interested parties as customers, suppliers, Government, employee and community. The expectations of stakeholders towards business are eventually increasing as they are expecting transparency and accountability from businesses. Organizations have been duly expected to pay back to the society what they have taken as recourses and the best way to pay back and release their responsibility is Corporate Social Responsibility. The corporate social responsibility could be understand as an activity towards society, environment, social ethics and economic issues.

Earlier the business was concerned only for profit, it was presumed at early 1990s, but over the decades the prime motive of business has changed from the wealth to health. The earlier concept was to maximize the wealth of the stakeholders but now it has started considering the health of the society. Business speed up under society uses natural resources, society and being used by society. Business has give and take relationship with society. Thus, the concept of wealth maximisation of stakeholders fails to comply with societal concept's external and internal factors equally. A business's felling of answerability towards the society and surroundings in which it exercise. Organizations indicate this responsibility 1 . As the process they follow to reduce wastage and pollution.2. The plans they structured for society as educational and social. 3 . With proper and adequate utilization of engaged recourses. 
Grey (1987), defined Corporate Social Responsibility "the process of conveying the bionomic and collective effects of business on society and economy for nation. The corporate social responsibility is beyond the financial report to the stakeholder but, annual report to the public about the resources used and activities conducted for the society. The meaning of business's responsibility towards society is creating security for society as well as with employees.

Carrol (1991) introduced the new concept by creating a CSR pyramid. He explains the CSR with different concept as: economic responsibility was basis of global capitalism, legal responsibility with laws and regulations, ethical responsibility with stakeholders, philanthropic activities with charity activates, towards the society.

By the time the concept of CSR had developed from charity to social responsibility. At present, the GRI (Global Report Initiative) and the UN Global Compact have introduced many new changes and guidelines for the corporate to follow. All of these developments and guidelines brought the inevitable results in the implication of corporate social responsibility.

\section{LITREATURE REVIEW}

CSR can be influenced by various factor and characteristics of firms. The disclosure depends upon many variable as firm's size, age, debt equity, turnover, profit, assets, legal processes of firm's, NGO involvement and corporate governance etc. generally it can be said in the case of age that older the company better will be the disclosure, same as in case of turnover larger and profitable is the unit the better will be the disclosure. The extent of debt will have greater effect on level of influence on CSR as compared to only equity capital.

Review of Literature provides a compelling role to the basis of every research methodology. It helps in specifying the methodology adopted by previous researchers and provide the support to make authentic comparison with the results of previous studies. In other words, literature of review is the seat of the knowledge of the new studies, and the track to quail in the existing sea.

There are a number of studies that have been conducted in India and in the other countries with the different name of the same aspect as environmental disclosure, environment reporting, social responsibility, social accounting. These studies are mostly descriptive qualitative and empirical studies that analyzed the disclosure practices in annual reports.

Dewan Mahboob Hossain (2018), the study conducted the analysis and participation of the stakeholders and regulators to ensure the balanced environmental disclosure of the companies. The study explored the listed companies in Dhaka stock exchange. The study covered the significant aspects related to CSR in Bangladesh, first, the present literature focused on the CSR only, second, the study focused to understand the language used for the environmental disclosure and for this the study used the Aristole's categories of rhetoric and finally the study focus over the social issues pertaining to the poor economy. The study took the listed companies as a sample when the study started there were 543 companies were registered but due to non availability of annual reports of the companies' only 308 i.e.56.72\% of companies were available with the proper records. Out of these 308 companies only 38 companies were found reporting the CSR in their annual report. The conclusion of the study comes out that only banking companies have some level of environmental disclosure. The outcome of the study revealed that to boost up the economy of the country, there should be legal mandatory obligations for the companies to report towards the CSR, social issues and environmental safety. 
E.Shvarts, A.Pakhalov, A.Knizhnikov and L.Ametistova (2018) the basic purpose of the study was examined that if an environmental rating could effectively use to increase transparency and improved environmental performance and applicability of International voluntary environmental standards attracts the foreign direct investment in Russia. To find out the results rating method was applied. To gather the data first analyzed what is important for the environment and second how to evaluate it. The sample selection has been done on the basis of the volume of the oil production; the lower limit was 1.5 million tons of oil. The 21 Russian companies were selected for the sample. The quantitative and qualitative data both had been considered. The study revealed that Russian companies are following the GRI guidelines for environmental disclosure. The study revealed that environmental disclosure enhances the financial performance of the companies.

Die Pujiati (2017) the study conducted to examine governance's impact, profitability, institutional ownership, independent board of commissioners and independent audit of the committee on the corporate environmental disclosure. The study took the Sharia banks as sample and studied the annual reports of the banks. The study used the multiple regression analysis to examine the data. The study selected the 35 banks and studied the annual reports for the period of 2009-13. The index was constructed with the 43 items. The study concluded that the only audit committee has a significant effect on the corporate responsibility disclosure. Further, the study suggested that the researcher could also take the Investment Account Holder as the base of the study for the detailed investigations.

Md Abdul KaiumMasud, SeongMiBae and Jong Dae Kim (2017) Bangladesh is ranked fourth with the worst air pollution. The study is based upon Bangladesh environmental conditions because of polluted industries. The primary objective of the study is to examine environmental disclosure and accounting of the companies. At, current situation in Bangladesh, they had given a legal framework for Environmental reporting and green accounting, but the current study is to analyze to that whether the banks following the emerging trends of ER and GR. The study also viewed the legal regulations and implications of the environment reporting. The study found that in Bangladesh, 29 guidelines have been provided by the government to be followed. For the sample of the study, 20 (67\%) listed banks from 30 listed banking companies have been selected, listed in the Dhaka stock exchange. The study, based on the annual reports of the banks so secondary data used and descriptive research design has been drafted for the study. In 2013, in Bangladesh banks have been provided with the new guidelines of Green banking, so the study was related to the pre and post era of the Green banking i.e.2010-2014. A model of the 12 categories has been developed to measure the annual environmental disclosure by the companies. The study observed that banks are initiating Green projects and also providing Green project loan at zero rate of return. The Banks initiated the promotion of environment friendly investment, energy conservation projects, waste management projects and clean water supply. The study found that the top 6 banks were the most transparent in their annual reports with a $85 \%$ disclosure, rest the average disclosure was $40-50 \%$. The study also found that in the waste management, tree plantation programs and air pollution the banks scored highest but in the awards for CSR activities banks were far behind from the other sectors. The study concluded that, Green accounting and environmental reporting is still a developing concept in Bangladesh but it took advancement in the air pollution control, waste management and social environmental emerging issues. The study found that, more than $90 \%$ of the banks disclosed both financial and non financial information both in the annual reports and $70 \%$ of banking companies also disclosing their information in the director's report, in vision and mission reports for authenticity. The Second purpose of the study was investigated the legal implication about the environment reporting in Bangladesh, it was observed that there were ample number of rules , regulations and guidelines provided by the Government but there was a lack of commitment through the political and business sectors. 
Dr. R. Maregoud and Bhimasha K. B (2015) the study analyzed the CSR activities of cement industry of India with provisions of the Companies Act, 2013. The data were fetched from the companies' annual reports, from the web sites and from the articles published by companies. The study took the sample companies of Gulbarga district of Karnataka. The study conducted with both primary and secondary data. Primary data collected by structured questionnaire and secondary data from annual reports, web sites and related articles. The study elaborates the new Companies Act, 2013 in details and followed the cement companies' CSR activities of the past era. The study revealed that the industry initiated many social activities as education programs, welfare, healthcare and social development.

BarnaliChaklader, and Puja Aggarwal Gulati (2015) The study was conducted to analyze the corporate environmental disclosure practices of companies working in India. The study took the 50 companies as the sample on the basis of turnover, and this list had been collected from the ET500. The study analyzed the environmental disclosure practices of these companies and the impact of the independent variable on the environmental disclosure index. The study classified the independent variable in 5 parts as Size, type of industry, Profitability, multinational status and environmental certification and financial leverage. The study analyzed annual reports of four years. The study analyzed that the in four years, it was significantly proved that size and environment certification affects the company and had a positive association. This relationship states that big size companies and environmental certification companies had better environmental disclosure. Environmental certification reduces the agency cost and monitoring cost, but no other variable had been found relevant. The study found that every variable had its own variations and no relation to disclosure.

\section{Affirmation of Problem}

Indian Corporate disclosure has improved over the years. The usefulness of annual reports and disclosure of certain items in the annual reports have been constantly increasing. The government has made it obligatory for the companies to disclose specific knowledge in the yearly reports. The new companies Act, 2013 under section 128(1), specify that companies should provide fair and clear picture to the public. Along with the profits and other investment the companies need to provide environmental disclosure i.e. about usage of natural recourses and CSR about investment in society.

In India, The new Companies Act 2013 regulates the environmental reporting and disclosure and made it compulsory for the companies to reveal proper data. The old companies Act, 1956 did not properly included the CSR and environmental disclosure thus the new companies Act, 2013 came with many new provisions inserted as an amendments in the law to make it more accountable and transparent. The present companies Act, is structured in a way that would provide a clear interpretation and would help in faster economic growth. The Act focused on the responsibilities towards society and investors. Thus, in order to compile with the Government the SEBI introduced various guidelines to protect the investor's interest and to maintain the standardized corporate governance regulatory.

The study selected the Pharmaceutical companies because the pharma industry is one of the major pollution produced sector in India. This study aims at analyzing the relationship between extent of corporate disclosure and age, assets and turnover of the companies.

\section{RESEARCH OBJECTIVE AND METHODOLOGY}

- Sample Selection: For the study one of the most pollution produced industry has been selected: pharmaceutical industry. The rational to select the listed companies is the availability of required data for the study. The listed companies are required to disclose and publish all the information in annual reports.In the research the sample of 
seven years data have been taken, as 2009-16 of the selected pharma companies. The 50 pharma companies have been selected as sample companies. The samples are collected by purposive sampling.

- Data Collection: The study is truly secondary data based. The extent of disclosure and environment reporting is totally annual reports based. The annual reports have been taken from the web site of the companies and from other online resources.

\section{Research Instruments}

To test the impact \& causes of environmental \& CSR disclosure the liner regression method has been used. The age, asset and, turnover have been taken as performance indicators of the companies.

\section{Objectives of the Study:}

General objective: The basic \& primary objective of study is to observe the association of corporate environmental accounting \& reporting with the some selected characteristics and indicators performance of pharmaceutical companies.

\section{Specific Objectives}

- To study the extent of environmental and social disclosure in term of "item wise" and "company wise disclosure".

- To study the association of corporate environmental accounting and reporting with some selected indicators ( age, assets and turnover) performance of Pharmaceutical companies.

\section{Hypothesis for the Study}

- $\mathrm{Ho}_{1}$ : There is no significant relation between age and disclosure of company.

- $\mathrm{Ho}_{2}$ : There is no significant relation between assets and disclosure of company.

- $\mathrm{Ho}_{3}$ : There is no significant relation between turnover and disclosure of company.

In the study to find the association between the CSR \& environmental disclosures and firm's financial performance: age, assets of firms and turnover of the 50 pharmaceutical companies have been selected. To find out the relation between disclosure $\&$ indicators of the companies the score of each company have been calculated. To calculate the score index have been prepared. The item wise disclosure has been calculated by adding the score of each item disclosed by the every company and dividing with the no. of companies. In the index that constructed for the study, contained the 147 items \& divided into 5 major categories. These major headings contained the informational items those according to the nature. The major categories are:

- Environment.

- Energy, Water \& Biodiversity.

- Human recourse.

- Carbon \& Harmful gases.

- Other CSR activities.

These each category contained the items that need to be disclosed by the company. These categories have been 
sub divided according to need \& expectation and contained the items on the basis of nature. The no. of items in every heading is:

Table 1: Items in Each Category in the Disclosure Index

\begin{tabular}{|l|c|c|}
\hline \multicolumn{1}{|c|}{ Category } & No. of items & \% of every section \\
\hline Environment. & 22 & 14.96 \\
\hline Energy,Water\&Biodiversity. & 29 & 19.72 \\
\hline Human recourse. & 55 & 37.41 \\
\hline Carbon \& Harmful gases & 24 & 16.32 \\
\hline Other CSR activities & 17 & 11.60 \\
\hline Total & 147 & 100 \\
\hline
\end{tabular}

(Source: Author's compilation)

Table no. 1 presents a brief description of Mean Discourse score i.e. value of Mean and S.D, of all the items in "Disclosure Index" complied during the year 2009-10, 2010-11, 2011-12, 2012-13, 2013-14, 2014-15, 2015-16.

Table 2: Mean Disclosure Scores of All the Items in "Disclosure Index"

\begin{tabular}{|c|c|c|}
\hline Year Wise Disclosure & Mean & S.D \\
\hline $2009-10$ & 21.0748 & 22.90214 \\
\hline $2010-11$ & 24.8425 & 25.12754 \\
\hline $2011-12$ & 29.6045 & 25.79651 \\
\hline $2012-13$ & 31.7143 & 25.83827 \\
\hline $2013-14$ & 32.5515 & 26.41489 \\
\hline $2014-15$ & 35.9048 & 27.67654 \\
\hline $2015-16$ & 43.1565 & 28.79776 \\
\hline
\end{tabular}

(Source: Author's compilation)

Table no. 2 presents a brief description of Mean Discourse score i.e. value of Mean and S.D, of all the items in "Disclosure Index" complied during the year 2009-10, 2010-11, 2011-12, 2012-13, 2013-14, 2014-15, 2015-16.

Table 3: Range of Disclosure Scores of All the Items in "Disclosure Index: 2009. 2016

\begin{tabular}{|c|c|c|c|c|c|c|c|}
\hline $\begin{array}{c}\text { \% of Items } \\
\text { (Averages) Disclosed } \\
\text { by Companies }\end{array}$ & $\mathbf{0 9 - 1 0}$ & $\mathbf{1 0 - 1 1}$ & $\mathbf{1 1 - 1 2}$ & $\mathbf{1 2 - 1 3}$ & $\mathbf{1 3 - 1 4}$ & $\mathbf{1 4 - 1 5}$ & $\mathbf{1 5 - 1 6}$ \\
\hline $0-15$ & 83 & 75 & 58 & 49 & 40 & 31 & 32 \\
\hline $15-30$ & 23 & 25 & 36 & 41 & 38 & 32 & 29 \\
\hline $30-45$ & 10 & 9 & 12 & 16 & 21 & 24 & 18 \\
\hline $45-60$ & 19 & 20 & 14 & 13 & 14 & 16 & 19 \\
\hline $60-75$ & 8 & 11 & 17 & 15 & 13 & 18 & 20 \\
\hline $75-90$ & 4 & 7 & 10 & 13 & 21 & 26 & 29 \\
\hline
\end{tabular}

(Sources: authors own compilation.)

The index complied with the 5 categories of items. The disclosure score sheet has been prepared on the basis of the disclosure of these items. The information categories contained 147 items in the index. The table summarized the average values of the disclosure score by the company. The table revealed the class interval, in which averages divided according to ranges. The above table revealed that in 2009-10 the maximum numbers of information items were disclosed between the ranges of 0-15, which clearly signifies the low disclosure score and only 4 falls in the range of 90 . In further years, the disclosure score increasing by increasing trend. In the year 2015-16, the disclosure score has the mixed range. That depicts the environmental and social accounting yet, not fully disclosed by the company. The lowest disclosure in the 2015-16 was 18 that revealed only 18 items were disclosed by the 30-45\% of the companies. 


\section{Corporate Attributes and The Extent of Corporate Information Disclosure}

The results of the above part of this study revealed the extent of corporate disclosure in the annual reports of the companies for the period of study i,e. 2009-10 to 2015-16. From the annual reports it has been analyzed that there is variation in the disclosure pattern and quantum of disclosure. The difference varies from year to year and company to company. These variations could be because of many factors most likely company's specific characteristics. In the related literature and past many studies, it has come forward that many researchers examined the relationship between attributes of the companies and disclosure of companies although, the results varies from company to company and country to country.

The present study examined the relationship between attributes of companies and extent of disclosure of 50 pharma companies. In the words of Gibbins," corporate disclosure is a management activity which can be explained by the specific context in which it occurs". Thus, there are some specific conditions and factors that facilitate the extent of disclosure and relationship evidence. The study provides the base to analyze the whether this kind of relationship is significant or not. The companies' characteristics considered for the study area:

- Age of the companies.

- Assets of the companies.

- Turnover of the companies.

The study is based on the secondary data collected from the annual reports of the companies over the period of seven years i.e. 2009-10, 2010-11, 2011-12, 2012-13, 2013-14, 2014-15 and 2015-16.

To analysis the data various statistical tools have been applied on the collected data. The analysis and interpretation based to examine the influence of company's particular characteristics on the extent of disclosure. Regression method has been used to find out the relationship between the variables and to study the influence of a single independent variable on the dependent variable. The regression analysis also helps to establish the effect of all independent variable on the dependent variable.

To signifies the study calculations have been made for the entire 7 years of the study. The following part of the study described the results of the liner regression method with the other factors.

\section{Simple Regression Analysis of Corporate Attributes with Disclosure by Companies Age of the Company}

It has been analyzed from the results that younger companies have the better disclosure score than the older companies. It could be because of the cost associated with the disclosure, the collection cost and old pattern followed by the old companies. Younger companies are facing competitive advantages and disadvantages due to this, it has become necessary for the companies to be in the prosperous dimple.

To statistically examine and test the relationship between age of the company and extent of information disclosure the following null hypothesis has been formulated for both the pharmaceutical and cement companies.

Ho 1: There is no significant relationship between age of the company and extent of disclosure of the company.

To test the above hypothesis following linear regression model has been used.

$$
\mathrm{Y}=\mathrm{b}_{\mathrm{o}}(\text { constant })+\mathrm{b}_{1} \mathrm{x}_{1}+\mathrm{e}
$$


Here,

$\mathrm{Y}=$ Extent of corporate information disclosure $=\mathrm{CDS}, \mathrm{b}_{\mathrm{o}}=$ Intercept, $\mathrm{b}_{1}=$ Regression coefficient of age, $\mathrm{x}_{1}=$ Ages of companies in years (Square root of age),Assest and turnovere $=$ error

The mentioned linear model has been used for the study to establish the relationship between age and extent of disclosure by the selected Indian Companies, for the years covered under the study.

The results of the study have been shown under the table number

Table 4: Linear Regression Results Age With Disclosure

\begin{tabular}{|c|c|c|c|c|c|}
\hline Year & Constant & Co-Efficient of Independent Variable & $\mathbf{R}^{\mathbf{2}}$ & $\mathbf{F}$-Value & Sig (P) Value \\
\hline $2009-10$ & 11.142 & .227 & .044 & 2.616 & $.012^{*}$ \\
\hline $2010-11$ & 22.613 & .108 & .012 & .565 & .056 \\
\hline $2011-12$ & 31.031 & .023 & .001 & .025 & .075 \\
\hline $2012-13$ & 29.147 & .030 & .001 & .042 & $.038^{*}$ \\
\hline $2013-14$ & 28.125 & .113 & .013 & .617 & $.036^{*}$ \\
\hline $2014-15$ & 28.703 & .162 & .026 & 1.3 & .060 \\
\hline $2015-16$ & 26.119 & .193 & .049 & 2.490 & $.023^{*}$ \\
\hline
\end{tabular}

(Source: Author's own compilation.)

If Probability (p) is less than .01= Highly Significant., If (p) is more than .01 but less than $.05=$ Significant.

If $(\mathrm{p})$ is more than $.05=$ not Significant.,Dependent variable: Disclosure score, Independent variable: Age.

From the above analysis it is concluded that there is positive relationship between age and disclosure of the companies in all the years of the study. The result is evidenced by the application of statistical regression model. Therefore the, null hypothesis that there is no a significant difference between the age and disclosure of the companies is rejected.

\section{Assets of the Company}

Rom the results it could be seen that the assets of the companies have the positive relationship with the disclosure of the companies. Thus, it could be analyzed after the application of statistical model on data that firms having higher level of total assets disclose more information about CSR than the firms who having lower level of total assets.

In order to examine the relationship between Assets of the companies and extent of information disclosure, the linear regression model has been applied. For application of statistical tools the following hypothesis has been formulated: Ho 2: There is no significant relationship between assets value and extent of disclosure.

Table 5: Linear Regression Results Assets with Disclosure

\begin{tabular}{|c|c|c|c|c|c|}
\hline Year & Constant & Co-Efficient of Independent Variable & $\mathbf{R}^{2}$ & F-Value & Sig(P)Value \\
\hline $2009-10$ & 18.11 & .359 & .129 & 7.099 & $.010^{*}$ \\
\hline $2010-11$ & 23.277 & .1991 & .036 & 1.817 & .184 \\
\hline $2011-12$ & 29.190 & .162 & .026 & 1.292 & .261 \\
\hline $2012-13$ & 3106777 & -.119 & .014 & .689 & .411 \\
\hline $2013-14$ & 34.877 & -0.96 & .119 & .447 & $.027^{*}$ \\
\hline $2014-15$ & 40.412 & .038 & .111 & .068 & $.005^{* *}$ \\
\hline $2015-16$ & 42.877 & 0.24 & .149 & .027 & $.001^{* *}$ \\
\hline
\end{tabular}

(Source: Author's compilation.)

From the above analysis it is concluded that there is positive relationship between assets and disclosure of the companies in 2009-10, 2013-14, 2014- 15 and 2015-16 the years of the study. In the years 2010-11, 2011-12 and 2012-13 the disclosure score and assets of the companies had the insignificant relation. The result is evidenced by the application of 
statistical regression model. Therefore the, null hypothesis that there is no significant difference between the assets and disclosure of the companies is rejected.

\section{Turnover}

The size of the company could be explain by the turnover and capital structure of the company. The turnover is the major explanatory variable for the disclosure of the company.

Over the years, many researches and studies have been taken on corporate disclosure with financial performance factors.

In the study, to test the relationship between turnover and disclosure of information the following null hypothesis has been set:

Ho 6: There is no significant relationship turnover and extent of disclosure.

Table 6: Linear Regression results Turnover with disclosure

\begin{tabular}{|c|c|c|c|c|c|}
\hline Year & Constant & Co-Efficient of Independentvariable & $\mathbf{R}^{2}$ & F-Value & Sig $(\mathbf{P})$ Value \\
\hline $2009-10$ & 17.569 & .264 & .070 & 3.379 & .073 \\
\hline $2010-11$ & 20.060 & .365 & .133 & 7.240 & $.010^{*}$ \\
\hline $2011-12$ & 25.966 & .261 & .068 & 3.450 & .070 \\
\hline $2012-13$ & 28.141 & .331 & .110 & 5.922 & $.019^{*}$ \\
\hline $2013-14$ & 34.825 & .332 & .110 & 5.932 & $.019^{*}$ \\
\hline $2014-15$ & 39.918 & .425 & .181 & 10.597 & $.002^{* *}$ \\
\hline $2015-16$ & 41.119 & .425 & .124 & 10.596 & $.007^{* *}$ \\
\hline
\end{tabular}

(Source: Author's own compilation.)

From the above analysis, it is concluded that there is positive relationship between Turnover and disclosure of the companies in the recent years of the study i.e. from 2009-10 and 2015-16. The result is evidenced by the application of statistical regression model. Therefore the, null hypothesis that there is no significant difference between the turnover and disclosure of the companies is rejected.

\section{CONCLUSIONS}

The analysis of the study revealed that there are few items which have 0 disclosure score. The results leave the impact that futuristic and forwards looking approach of those items is slow. These items are uses of environment friendly material, prevention or repair of the damage to the environment, initiatives from rain, water and harvesting, certified management system, total direct energy consumption in Jules or multiple by renewable primary sources, the total primary energy consumed and its total, existing initiates reduce the energy requirements, size and location of all habitat areas, receiving a safety award, employment to differently able people, subsidized canteen, feedback from employees, information on physical handicapped employees, information on labor contacts, members regarding serious disease, efforts to reduce carbon emission, signatory to MOU with regard to emission and initiatives for social afforestation not been disclosed by any of the sample com[any during the period of the study.

The overall disclosure of the items revealed the improvement in the disclosure. The informational item showed the improvement up to 50 percent in the disclosure. It could be analysed from the results that New Companies Act, 2013 yield the great improvement in the disclosure by the companies and in CSR investment. The results indicated the positive improvement in the disclosure. The study inference that the age turnover and assets are the important factors for the 
disclosure of companies, in consideration of pharmaceutical companies.

\section{Recommendation in Consideration of Present Study}

The corporate reporting and corporate discourse need to be study from all the perspectives. The transparency, corporate reporting and corporate governance increase the worth for stakeholders. Therefore, to enhance the adequacy of corporate disclosure and reporting certain recommendation and suggestions are made that might be helpful for future perspectives.

- The companies are required to disclose more voluntary items with the mandatory items. The adherence by top management regarding fair disclosure could only achieve by the voluntary and mandatory with financial and nonfinancial disclosure.

- The disclosure should be in such a way that it shall be useful for future projects. The CSR s should be based on forward looking approach.

- The present study shows a gloomily image of the disclosure and reporting by the pharmaceutical sectors. In response to changing demand of time, the companies need to make voluntary disclosure and social activities. Management should understand the need of disclosure of non-financial information to create the better image if company and inclination of interested groups of stakeholders as well.

- Considering the noticeable variation of the companies which have been awarded as best CSR policy and best human recourses have the better environment disclosure and increases it year by year. The reorganisation of companies by awarding best among the all, provides the more efficiency to the companies for betterment.

- Further, in the present study the annual reports are also lacking of HRA and audit. The government should develop the models and implement these models practically. The HRA audit ensures the right recourses on right place which information might be useful from the stakeholder's point of view.

\section{REFERENCES}

1. Archambault, JJ..\&Archambault. ME, 2003 “A Multinational test of Determinants of Corporate Disclosure”., International Journal of Accounting ., (38) Pp. 173-194.

2. Bowonder, B., and S, S Arwind.,1989 “Environmental Regulation and Litigation in India” Environmental Impact,4(4). pp. 182-196. From the website https://www.tandfonline.com

3. Business strategies for sustainable development, 2018.,from the web site https//www.iisd.org/ business/pdf/business_strategy.pdf. Assessed on the date 24-7-2019.

4. Caroll, A.B.1991 "The Pyramid of Corporate Social Responsibility : Toward the Moral Management of Organizational Stakeholders" Business Horizons 34, pp.39-48.

5. Carroll, Archie B.2008 "A History of Corporate Social Responsibility: Concepts \& Practices”. Research Gate, In Andrew Crane, AbigaliMc Williams, DrikMatten, jeremy Moon \& Donald Siegel (eds). The Oxford Handbook of Social corporate responsibility press, 1946.DOI:10.1093/oxfordhb/9780199211593.003.0002. from website https://www.researchga-+++-te.net/publication/282746355.

6. Cerf, A. R.1961, “Corporate Reporting \& Investment Decision”. Berkeley, University of California Press.

7. Chaklader, Barnali., amd Puja AggarwalGulati., 2015 "A Study of Corporate Environmental Disclosure Practices of Companies Doing Business in INDIA” Global Business Review ., DOI: 10.1177/09721509, 4564430, 16(2)Pp. 321-335.

8. Chaklader, Barnali., and Gulati, Puja Aggarwal., 2015 "A Study of Corporate Disclosure Practices of Companies Doing Business in India", Global Business Review., 16(2). pp. 321-335. From website https://doi.org/10.1177/09721509145464430. 
9. Gray, R., Kouhy, R., and Lavers, S., 1995“ Corporate Social and Environmental Reporting: A Review of the Literature and A Longitudinal Study of UK Disclosure” Accounting Auditing and Accountability Journal., 8(2).pp.47-77.

10. Grey, Rob.,owen, Dave., and Maunders, Keith.1988, 'Corporate Social Reporting : Emerging trends in Accountability and the Social Contract”, Accounting, Auditing \& Accountability Journal., 1 (1), pp.6-20.

11. GRI's Contribution to Sustainable Development, 2016., GRI Empowering Sustainable Growth. From the website: https://www.globalreporting.org.

12. Hossain, DewanMahboob.2018“ Rhetoric as a form of Persuasion in Disclosing Poverty - Related CSR Activities in Corporate Disclosure: The Case of Bangladesh',30 April, from web site www.reserachgate.net.

13. http://envfor.nic.in/division/environment-protection. Assess on $3^{\text {rd }}$ April, 2019.

14. http://vips.edu/wp-content/uploads/2017/07/Mandatory.pdf. Navjeet. 2017“ India's Mandatory CSR Law : Issues \&Challenges”.

15. Hussain, MohamadDelwar.,Wahidah, Sitinur., BakarRosni., and Bhuiyan, Abul Bashar.2016"Environmental Accounting and Sustainable Development : An Empirical Review” research gate., from website http://www.researchgate.net/publication/303279145.

16. Jensen, M C and Mecking, M.H.1976"Theory of firm, managerial behaviour, agency cost and ownership structure", Journal of financial Economics, (3), pp.305.

17. Levashova, Yulia.2018“The Accountability and Corporate Social Responsibility of Multinational Corporation for Transgressions in Host States through International Investment Law” Utrecht Law Review., 14(2). From website

18. Masud, Md Abdul Kaium., Bae, Seong Mi., and Kim, Jong Dae.,2017 “Analysis of Environmental Accounting \& Reporting Practices of Listed Banking Companies in Bangladesh”MDPI.,Sustainability 2017, 9,1717;doi10.3390/su9101717.

19. Maregound, R., and Bhimasha,K.B.,2015"Corporate Social Responsibility In Cement Industry: A Study with A Special References To Select Units In Gulbarga District of Karnataka', International Journal in Management \& Social Science.,3(3), pp.427-439. From website http://www.ijrm.net.in.

20. Miller, M.H., and Rock, K.,1985 “Dividend Policy Under Asymmetric Information” Journal of Finance., 45, pp.1031-1051.

21. Pujiati, Diyah.,2017, “ Corporate Social Responsibility Factors at Sharia Banks in Indonesia”, International Journal of Economic Research.,14(15).Fromwebsite https:www.researchgate.net/publication/321705029.

22. Shvarts, E., Pakhalov, A., Knizhnikov,A., Ametistova, L.2018 "Environmental rating of Oil and Gas Companies in Russia: How assessment affects environmental transparency and performance" Wiley Business strategy \& the environment.,DOI:10.1002/bse.2049.Fromwebsite:https//www.reserachgate.net/publication/324173070. 

